\title{
The Victor Diamond Mine (Superior Craton, Canada) - A new paradigm for exploration in unconventional settings
}

\author{
Thomas Stachel ${ }^{1}$, Anetta Banas ${ }^{2}$, Sonja Aulbach ${ }^{1,3}$, Karen V. Smit ${ }^{1,4}$, Pamela Wescott ${ }^{1}$, \\ Ingrid Chinn $^{5}$, David Fisher ${ }^{6}$ and Julie Kong ${ }^{7}$ \\ ${ }^{1}$ University of Alberta, Edmonton, Canada, tstachel@ualberta.ca \\ ${ }^{2}$ APEX Geoscience Ltd., Edmonton, Canada, abanas@apexgeoscience.com \\ ${ }^{3}$ Goethe-Universität, Frankfurt, Germany, s.aulbach@em.uni-frankfurt.de \\ ${ }^{4}$ Gemological Institute of America, New York, USA, ksmit@gia.edu \\ ${ }^{5}$ De Beers Exploration, Southdale, South Africa, Ingrid.Chinn@ debeersgroup.com \\ ${ }^{6}$ De Beers Technologies UK, Maidenhead,UK, David.Fisher@debeersgroup.com \\ ${ }^{7}$ De Beers Canada, Toronto, Canada, Julie.Kong@debeersgroup.com
}

\section{Introduction}

The James Bay area on the Superior Craton is host to kimberlites of Mesoproterozoic ( 1.1 Ga; Kyle Lake kimberlites) and Jurassic age ( 180-170 Ma; Attawapiskat kimberlites; Januszczak et al. 2013). De Beers' Victor Mine is part of the Attawapiskat kimberlite field and derives a diamond production of superb quality from a geologically discrete phase (Victor Main) within the North pipe and from the SW pipe. At $1.1 \mathrm{Ga}$ the area was affected by a thermal event that likely represents the northern extension of the major Midcontinent Rift, impacting the Superior Craton from the South. This thermal event is documented in an elevated geotherm $\left(40-41 \mathrm{~mW} / \mathrm{m}^{2}\right.$ reference geotherm of Hasterok and Chapman 2011) derived from mantle xenocrysts in Kyle Lake kimberlites, reflecting a small diamond window in the lithospheric mantle between 140-180 km depth (Smit et al. 2014). For the Jurassic Attawapiskat kimberlites, xenocrysts indicate a "cool" cratonic geotherm $\left(39 \mathrm{~mW} / \mathrm{m}^{2}\right)$ associated with a large diamond window (120-200 km; Smit et al. 2014).

\section{James Bay area diamond populations}

An infra-red spectroscopic study of nitrogen concentrations and aggregation states in diamonds from Mesoproterozoic (T1) and Jurassic (U2) kimberlites revealed distinct diamond populations (Fig. 1; Smit et al. 2014). Diamonds in the older T1 kimberlite are characterized by low nitrogen concentrations (typically <80 at.ppm) and high aggregation states (all $>70 \% \mathrm{~B}$; median: $87 \% \mathrm{~B}$ ). Diamonds in the Jurassic U2 kimberlite, however, typically show high nitrogen contents (median 290 at.ppm) at low aggregation states (median: $12 \% \mathrm{~B}$ ). Our data for Victor diamonds display this Jurassic signature of high nitrogen contents (median: 460 at.ppm) and low aggregation states (median: $20 \% \mathrm{~B}$ ) even more prominently (Fig. 1). As aggregation of nitrogen into B centres is an irreversible process, the distinct diamond populations sampled by Mesoproterozoic and Jurassic kimberlites imply diamond destruction, presumably in the course of the $1.1 \mathrm{Ga}$ Midcontinent Rift event, followed by renewed diamond formation. This conclusion is supported by distinct carbon isotopic signatures for the two age groups, with diamonds in the Mesoproterozoic T1 kimberlite showing a narrow mode in $\delta^{13} \mathrm{C}$ at -3.5 to $-2.5 \%$ (median: $-3.3 \%$, Fig. 2) which is shifted to -6.0 to $-5.0 \%$ (median: $-5.3 \%$ ) for the Jurassic U2 and Victor kimberlites.

\section{Age of Diamond Formation}

Geologically "young" diamond formation beneath the Western Superior Craton, postdating the Midcontinent Rift event, is entirely consistent with the outcomes of our Re-Os dating study based on 20 sulfide inclusions released from 19 Victor diamonds, which produced a robust model-3 isochron age of $718 \pm 49 \mathrm{Ma}$ (Aulbach et al., this volume). This diamond age agrees with models for lithosphere-scale dissipation of thermal events that indicate thermal relaxation over $\sim 0.4 \mathrm{Ga}(95 \%$ decay for $200 \mathrm{~km}$ thick lithosphere; Vitorello and Pollack 1980). Our 720 Ma age also overlaps with the break-up of the Rodinia supercontinent, which may have triggered the mobilisation of carbon-bearing fluids or melts. 


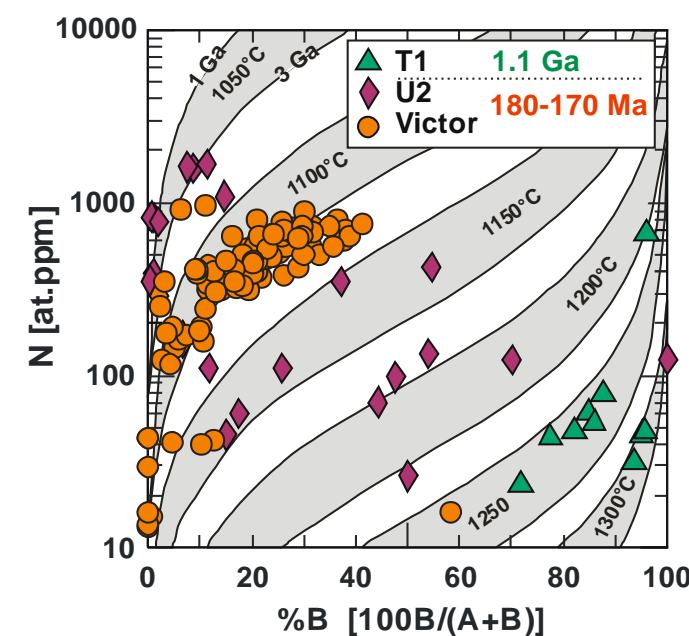

Figure 1: Nitrogen content versus nitrogen aggregation state (as relative percentage of nitrogen in fully aggregated B-centers) for diamonds from Mesoproterzoic (T1) and Jurassic kimberlites (U2, Victor) in the James Bay area.

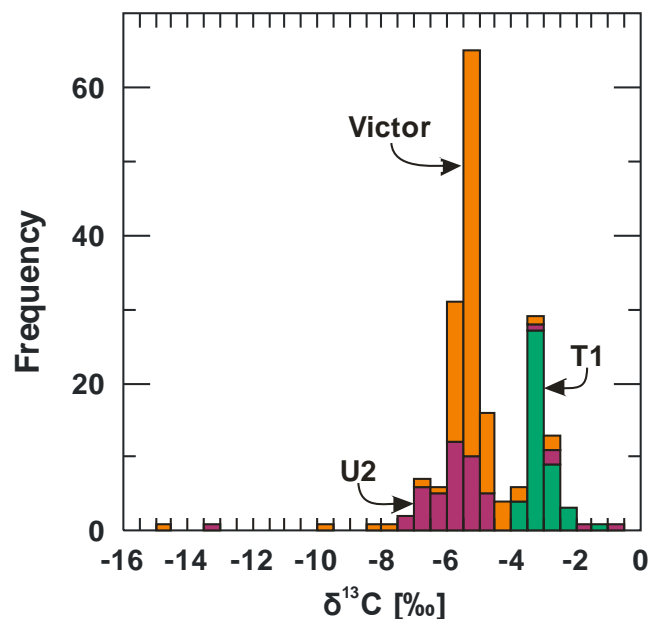

Figure 2: Carbon isotopic composition of diamonds from Mesoproterzoic (T1) and Jurassic kimberlites (U2, Victor). Values for T1 and $\mathrm{U} 2$ are averages of mulitple SIMS analyses per diamond (from Smit et al. 2014), Victor diamonds represent bulk analyses.

\section{Diamond Substrates in the Lithospheric Mantle beneath Attawapiskat}

We studied the paragenesis and the major and trace element composition of mineral inclusions in 116 diamonds from Victor. Based on 99 diamonds with classified silicate and sulphide inclusions, $87 \%$ of Victor diamonds belong to the peridotitic and $13 \%$ to the eclogitic suite. The peridotitic inclusion assemblage consists principally of garnet (63\%) and olivine (14\%), with minor (<10\% each) orthopyroxene, clinopyroxene and sulphides. Mg-chromite inclusions are completely absent. Considering only diamonds with peridotitic inclusions for which a specific paragenesis could be derived $(n=65)$, $97 \%$ belong to the lherzolitic and 3\% to the wehrlitic paragenesis, whilst harzburgitic inclusions are completely absent (shown for garnet inclusions in Fig. 3). Chemically, the lherzolitic association represents moderately depleted cratonic peridotites, with olivine Mg-numbers (91.3 \pm 0.2 , Fig. 4) below world wide average. Sinusoidal $\mathrm{REE}_{\mathrm{N}}$ patterns for garnet inclusions imply an absence of melt metasomatism. The eclogitic inclusion suite $(\mathrm{n}=18)$ is dominated by garnet, $\mathrm{SiO}_{2}$ (presumably primary

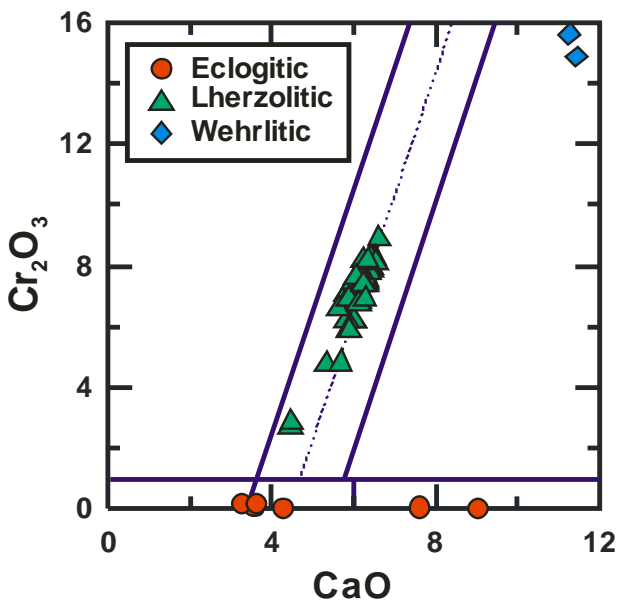

Figure 3: Cr-Ca plot for garnet showing the overwhelmingly lherzolitic paragenesis of inclusions in Victor diamonds. Note that the Victor lherzolitic garnets overlap the division (thin dashed line) between diamond-associated G9A and graphite-associated G9B garnets of Grütter and Menzies. (2003).

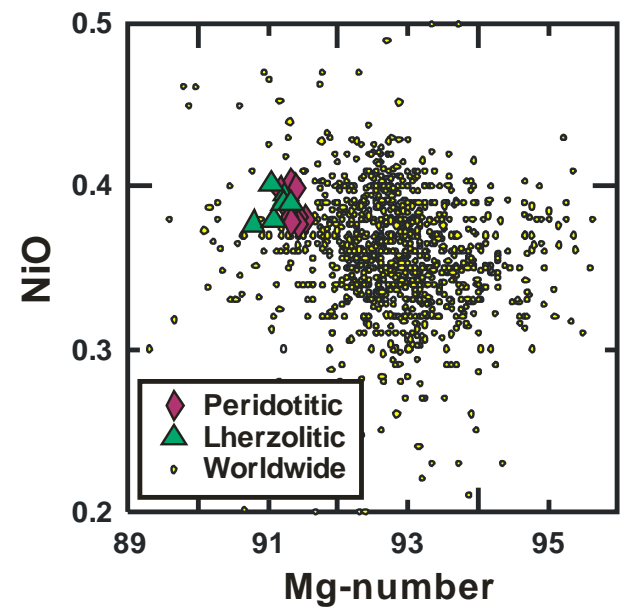

Figure 4: $\mathrm{NiO}$ versus $\mathrm{Mg}$-number for olivine inclusions in Victor diamonds. Olivines without coexisting garnet or clinopyroxene inclusions cannot be further classified and are labelled "peridotitic". Peridotitic olivine inclusions from diamonds worldwide are shown for comparison. 
coesite) and sulphide inclusions, with single occurrences of clinopyroxene, kyanite and a mica-ilmenite intergrowth. For six of the 13 eclogitic diamonds, inclusions were recovered from fibrous coats.

\section{Geothermobarometry}

Nitrogen-in-diamond based thermometry (Leahy and Taylor 1997) for Victor inclusion-bearing diamonds indicates a narrow interval in mantle residence temperatures $\left(1142 \pm 24{ }^{\circ} \mathrm{C}\right)$ bracketing the average for diamonds worldwide $\left(\sim 1150{ }^{\circ} \mathrm{C}\right)$. Projection of these temperatures onto the Attawapiskat paleogeotherm reveals diamond sampling from a thin layer at $163 \pm 4 \mathrm{~km}$ depth. Temperature estimates based on five clinopyroxene inclusions yield $1120 \pm 20{ }^{\circ} \mathrm{C}$ at an assumed pressure of $50 \mathrm{kbar}$ (thermometer of Nimis and Taylor 2000; none of the inclusions pass the compositional filters of Ziberna et al. 2016 for pressure calculations). Projection of clinopyroxene-derived temperatures onto the local paleogeotherm results in a depth of sampling of $158 \pm 4 \mathrm{~km}$. Using Ni-in-garnet thermometry (Canil 1999), the peak mantle entrainment for the Victor Main high grade unit occurred at about $153 \pm 10 \mathrm{~km}$ depth (Januszczak et al. 2013; their Fig. 8), implying fortuitously efficient sampling of this well-defined diamondiferous layer.

\section{Conclusions}

Guided by Clifford's Rule and paragenetic diamond associations defined via inclusion studies (e.g., Gurney 1984), exploration focusses on harzburgitic and eclogitic diamond substrates associated with Archean cratons. The Victor Mine, however, exploits a 720 million year old lherzolitic diamond population derived from a section of sub-cratonic lithospheric mantle that experienced a diamond destructive thermal event $1.1 \mathrm{Ga}$ ago. This establishes Victor as an unconventional diamond deposit. As its key outcome, our study implies that future exploration programs in unconventional settings should pay close attention to diamond facies lherzolitic garnets during indicator mineral assessment.

\section{References}

Canil D (1999) The Ni-in-garnet geothermometer: calibration at natural abundances. Contributions to Mineralogy and Petrology 136:240-246

Grütter H, Menzies A (2003) Mutually consistent classification schemes for mantle-derived garnet and chromite, for use by diamond explorers. In: 8th International Kimberlite Conference, Victoria (Canada), Extended Abstracs (CD), pp 1-5

Gurney JJ (1984) A correlation between garnets and diamonds in kimberlites. In: Glover JE, Harris PG (eds) Kimberlite occurrence and origin: a basis for conceptual models in exploration, Vol 8. Publs Geol Dept \& Univ Extension, Univ West Aust, Perth, pp 143-166

Hasterok D, Chapman DS (2011) Heat production and geotherms for the continental lithosphere. Earth and Planetary Science Letters 307(1-2):59-70

Januszczak N, Seller MH, Kurszlaukis S, Murphy C, Delgaty J, Tappe S, Ali K, Zhu J, Ellemers P (2013) A multidisciplinary approach to the Attawapiskat Kimberlite Field, Canada: Accelerating the discovery-to-production pipeline. In: Pearson DG et al. (eds) Proceedings of the $10^{\text {th }}$ International Kimberlite Conference, Vol 2, Springer India, New Delhi, pp 157-171

Leahy K, Taylor WR (1997) The influence of the Glennie domain deep structure on the diamonds in Saskatchewan kimberlites. Russian Geology and Geophysics 38(2):481-491

Nimis P, Taylor WR (2000) Single clinopyroxene thermobarometry for garnet peridotites. Part I. Calibration and testing of a Cr-in-cpx barometer and an enstatite-in-cpx thermometer. Contributions to Mineralogy and Petrology 139(5):541-554

Smit KV, Stachel T, Stern RA (2014) Diamonds in the Attawapiskat area of the Superior craton (Canada): evidence for a major diamond-forming event younger than $1.1 \mathrm{Ga}$. Contributions to Mineralogy and Petrology 167(1):1-16

Vitorello I, Pollack HN (1980) On the variation of continental heat flow with age and the thermal evolution of continents. Journal of Geophysical Research: Solid Earth 85(B2):983-995

Ziberna L, Nimis P, Kuzmin D, Malkovets VG (2016) Error sources in single-clinopyroxene thermobarometry and a mantle geotherm for the Novinka kimberlite, Yakutia. Am Miner 101:2222-2232 